\title{
Seroprevalence of HbsAg, Anti-HBc and Anti-HCV in Southern Brazil, 1999-2001
}

\author{
Nilton Rosini, Donaida Mousse, Celso Spada \\ and Arício Treitinger
}

\begin{abstract}
Clinical Analyses Department, Health Sciences Center, Santa Catarina Federal University, Florianópolis , SC, Brazil
\end{abstract}

The prevalence of infection by the hepatitis $\mathrm{B}(\mathrm{HBV})$ and $\mathrm{C}(\mathrm{HCV})$ viruses varies among geographical regions. We evaluated 263,795 blood donor samples collected from 1999-2001 in various cities in the state of Santa Catarina to determine the prevalence of HbsAg, anti-HBc and anti-HCV markers. The markers were analyzed by immunoenzymatic tests, as determined by the Ministry of Health, and the data were obtained from blood banks and from ANVISA (the Brazilian National Agency for Sanitary Vigilance). There was a significant reduction in the mean frequency of HbsAg and anti-HBc during the study period, from $0.98 \%$ to $0.64 \%$ and from $8.83 \%$ to $5.35 \%$, respectively, though they varied considerably among the different regions. There was also a decrease in the mean frequency of anti-HCV, although it was not significant, decreasing from $0.38 \%$ to $0.34 \%$. Even with this reduction, the frequency of these markers was still high compared with that found in other countries, indicating high rates of infection by hepatitis $B$ and $C$ viruses. This emphasizes the urgency of vaccination programs against HBV, especially in some regions of Santa Catarina state, in order to reduce the prevalence of this infection and consequently reduce the risk of transmission through sexual relations or from the donation of blood and/or hemocomponents.

Key Words: Blood donors, hepatitis B, hepatitis C, HbsAg, anti-HBc, anti-HCV.

Infection by the hepatitis $\mathrm{B}(\mathrm{HBV})$ and hepatitis $\mathrm{C}$ ( $\mathrm{HCV})$ viruses is the most common cause of posttransfusion hepatitis [1,2]. However, with the emergence of HIV infection more emphasis has been given to the control of blood utilized in transfusions and in 1993 it became obligatory, in Brazil, to screen blood donors for $\mathrm{HBV}$ and HCV [3]. Furthermore, HBV and HCV are also the most frequent causes of chronic hepatitic diseases in the world, and their transmission occurs, mainly, through direct contact with blood, through the utilization of intravenous drugs, blood transfusions and/or

Received on 05 December 2002; revised 25 July 2003.

Address for correspondence: Dr. Aricio Treitinger PhD. Departamento de Análises Clínicas, Centro de Ciências da Saúde, Universidade Federal de Santa Catarina. Caixa Postal 476. Zip Code: 88040-900, Florianópolis - SC - Brasil. Phone:(48)3319712. Fax 3319542.E-mail aricio@ccs.ufsc.br

The Brazilian Journal of Infectious Diseases 2003;7(4):262-267 (C) 2003 by The Brazilian Journal of Infectious Diseases and Contexto Publishing. All rights reserved. hemocomponents, and through sexual relations. However, sexual relations seem not to be the most frequent mode of HCV transmission [4].

Infection by these two viruses may induce chronic hepatitis, which may progress to cirrhosis, and eventually to hepatocellular carcinoma [5-8]. It is estimated that around 350 million people in the world are chronic carriers of $\mathrm{HBV}$, which represents approximately $7 \%$ of the total population [9], whereas infection with $\mathrm{HCV}$ is found in approximately $3 \%$ of the world population, which represents 160 million people [10-12]. This high prevalence of $\mathrm{HBV}$ and/or HCV certainly results in high medical costs, due to a great number of cases of fulminating hepatitis, hepatic cirrhosis and carcinoma, and also provokes the death of a significant part of the population by these pathologies.

Studies show that a co-infection by HBV and $\mathrm{HCV}$ is as frequent in Asia $[13,14]$ as it is in western countries $[15,16]$, varying from $10 \%$ to $15 \%$ in patients who are chronically infected by HBV. Patients 
infected simultaneously by HBV and HCV are more frequently infected with the more severe hepatitic diseases and are at a significantly greater risk of developing fulminant hepatitis, hepatic cirrhosis and carcinoma $[17,18]$, particularly in the underdeveloped and/or developing countries, where the prevalence of simultaneous infections by these viruses appears to be higher. Also, the high prevalence of HBV and HCV may result in an increase in the risk of transmission of these viruses through the transfusion of hemocomponents, since it is not possible to totally guarantee the absence of these infections among blood donors through the serologic tests utilized routinely in the screening of blood donors [19].

We evaluated the prevalence of $\mathrm{Hbs} \mathrm{Ag}$, anti-HBc and anti-HCV markers among blood donors of the different regions of the state of Santa Catarina, Brazil, in 1999, 2000 and 2001.

\section{Materials and Methods}

The data were obtained from the data processing centers of the blood banks of the Centro Hemoterápico Blumenau (Blumenau Hemotherapeutic Center Blumenau-SC), Hospital Dona Helena (Dona Helena Hospital - Joinville-SC), Hemocentro Jaraguaense LTDA (Jaraguaense Hemocenter Ltd - Jaraguá do SulSC), Banco de Sangue do Hospital Universitário (University Hospital Blood Bank - Florianópolis - SC), Centro de Hematologia e Hemoterapia de Santa Catarina-Hemosc - (Hematology and Hemotherapy Center of Santa Catarina - Florianópolis-SC) and Agência de Vigilância Sanitária ANVISA - (National Health Agency) [20].

The research on markers of infection by HBV and by HCV was carried out by immunoenzymatic tests according to Ministry of Health directives No. 1376 of 1993 and No. 121 of 1995.

\section{Results}

The prevalence of HbsAg and anti-HBc markers varied among the different regions of the state of Santa
Catarina; from 1999 and 2001 the mean prevalence in the state declined progressively. The highest prevalence of these two markers was found in the region of the town of Chapecó, in western Santa Catarina (Tables 1 and 2).

The mean prevalence of anti-HCV in the state of Santa Catarina did not change significantly from 1999 to 2001, though it varied among regions (Table 3).

\section{Discussion}

Blood donors are interviewed with screening questionnaires, which have evolved over the years [21,22]. In the United States, since 1992, following recommendations from the Food and Drug Administration, donors are directly questioned about behavioral habits [23]. This modification in the screening of the donors resulted in a decrease in the prevalence of HCV from $0.63 \%$ in 1992 to $0.40 \%$ in 1996 among new blood donors [24], whereas among the general population, at the same time, the prevalence of this virus was $1.8 \%$ [25]. In the case of $\mathrm{HbsAg}$, a prevalence close to $0.2 \%$ was found, and there was no significant change from 1991 to 1996 [22]. In Brazil, where there is greater endemicity of $\mathrm{HBV}$, as we know that the prevalence of $\mathrm{HbsAg}$ and anti-HBc among the blood donors in 2001 was similar to the prevalence among the general population of Germany [26], it appears that the anti- $\mathrm{HBc}$ research has assisted in the identification of $\mathrm{HBV}$ carriers who are seronegative for $\mathrm{HbsAg}$ [27].

The prevalence of infection by HCV among the blood donors in the state of Santa Catarina in 1999 was similar to that found among new blood donors in the United States in 1996 [24,28]. In Santa Catarina, the prevalence of $\mathrm{HCV}$ among blood donors decreased considerably between 1994/1995 and 1999 [19,28], but there was only a small reduction between 1999 and 2001. Among blood donors in the state of Santa Catarina there was a significant decrease in the prevalence of HbsAg and anti-HBc between 1999 and 2001 (Tables 1 and 2). However, the mean frequency of the markers of infection by HBV (HbsAg and anti$\mathrm{HBc}$ ) among blood donors in the state of Santa Catarina from 1999 to 2001 only decreased to levels similar to 
Table 1. Prevalence of HbsAg among blood donors of the main regional blood banks of Santa Catarina

\begin{tabular}{|c|c|c|c|c|c|c|}
\hline \multirow{2}{*}{$\begin{array}{l}\text { Year and } \\
\text { Location }\end{array}$} & \multicolumn{2}{|c|}{1999} & \multicolumn{2}{|c|}{2000} & \multicolumn{2}{|c|}{2001} \\
\hline & $\mathbf{N}$ & $\%$ & $\mathbf{N}$ & $\%$ & $\mathbf{N}$ & $\%$ \\
\hline Florianópolis & $176 / 24.570$ & 0.71 & $280 / 24.274$ & 1.15 & $159 / 27.396$ & 0.58 \\
\hline Lages & $17 / 6.626$ & 0.26 & $16 / 5.899$ & 0.27 & $24 / 6.509$ & 0.37 \\
\hline Joaçaba & $64 / 8.036$ & 0.80 & $30 / 5.633$ & 0.53 & $27 / 5.668$ & 0.48 \\
\hline Chapecó & $375 / 11.713$ & 3.20 & $149 / 9.132$ & 1.63 & $122 / 7.909$ & 1.54 \\
\hline Criciúma & $36 / 7.193$ & 0.50 & $20 / 6.858$ & 0.29 & $23 / 7.493$ & 0.31 \\
\hline Joinville & $86 / 14.715$ & 0.58 & $63 / 13.957$ & 0.45 & 79/14.994 & 0.53 \\
\hline Tubarão & $27 / 2.420$ & 1.12 & $7 / 2.899$ & 0.24 & $22 / 2.804$ & 0.78 \\
\hline Blumenau & $92 / 13.704$ & 0.67 & $106 / 13.407$ & 0.79 & $85 / 12.580$ & 0.85 \\
\hline Jaraguá do Sul & $20 / 2.201$ & 0.91 & $17 / 2.317$ & 0.73 & $20 / 2.888$ & 0.69 \\
\hline Total & 893/91.358 & 0.98 & $688 / 84.376$ & 0.84 & $561 / 88.241$ & 0.64 \\
\hline
\end{tabular}

Table 2. Prevalence of anti-HBc among blood donors of the main regional blood banks of Santa Catarina

\begin{tabular}{|c|c|c|c|c|c|c|}
\hline \multirow{2}{*}{$\begin{array}{l}\text { Year } \\
\text { Location }\end{array}$} & \multicolumn{2}{|l|}{1999} & \multicolumn{2}{|l|}{2000} & \multicolumn{2}{|l|}{2001} \\
\hline & $\mathbf{N}$ & $\%$ & $\mathbf{N}$ & $\%$ & $\mathbf{N}$ & $\%$ \\
\hline Florianópolis & $1.303 / 24.570$ & 5.30 & $1.097 / 24.274$ & 4.52 & $968 / 27.396$ & 3.53 \\
\hline Lages & $157 / 6.626$ & 2.37 & $106 / 5.899$ & 1.80 & $138 / 6.509$ & 2.12 \\
\hline Joaçaba & $736 / 8.036$ & 9.16 & $354 / 5.633$ & 6.28 & $247 / 5.668$ & 4.36 \\
\hline Chapecó & $3.401 / 11.713$ & 29.04 & $1.632 / 9.132$ & 18.09 & $1.066 / 7.909$ & 12.72 \\
\hline Criciúma & $469 / 7.193$ & 6.52 & $263 / 6.858$ & 3.83 & $221 / 7.493$ & 2.95 \\
\hline Joinville & $1.055 / 14.715$ & 7.17 & $951 / 13.957$ & 6.81 & $635 / 14.994$ & 4.23 \\
\hline Tubarão & $134 / 2.420$ & 5.54 & $79 / 2.899$ & 2.73 & $110 / 2.804$ & 3.92 \\
\hline Blumenau & $565 / 13.704$ & 4.12 & $1.251 / 13.407$ & 9.33 & $1.164 / 12.580$ & 9.25 \\
\hline Jaraguá do Sul & $244 / 2.201$ & 11.10 & $17 / 2.312 .317$ & 9.97 & $234 / 2.888$ & 8.10 \\
\hline Total & 8.064/91.358 & 8.83 & $5.984 / 84.376$ & 7.09 & 4.723/88.241 & 5.35 \\
\hline
\end{tabular}

Table 3. Prevalence of anti-HCV among blood donors of the main regional blood banks of Santa Catarina

\begin{tabular}{|c|c|c|c|c|c|c|}
\hline \multirow{2}{*}{$\begin{array}{l}\text { Year } \\
\text { Location }\end{array}$} & \multicolumn{2}{|l|}{1999} & \multicolumn{2}{|c|}{2000} & \multicolumn{2}{|c|}{2001} \\
\hline & $\mathbf{N}$ & $\%$ & $\mathbf{N}$ & $\%$ & $\mathbf{N}$ & $\%$ \\
\hline Florianópolis & $133 / 24.570$ & 0.54 & $80 / 24.274$ & 0.33 & $102 / 27.396$ & 0.46 \\
\hline Lages & $18 / 6.626$ & 0.27 & $10 / 5.899$ & 0.17 & $17 / 6.509$ & 0.26 \\
\hline Joaçaba & $17 / 8.036$ & 0.21 & $10 / 5.633$ & 0.18 & $23 / 5.668$ & 0.41 \\
\hline Chapecó & $39 / 11.713$ & 0.33 & $17 / 9.132$ & 0.19 & $17 / 7.909$ & 0.21 \\
\hline Criciúma & $42 / 7.193$ & 0.58 & $27 / 6.858$ & 0.39 & $30 / 7.493$ & 0.40 \\
\hline Joinville & $27 / 14.715$ & 0.58 & $26 / 13.957$ & 0.19 & $27 / 14.994$ & 0.18 \\
\hline Tubarão & $25 / 2.420$ & 0.18 & $10 / 2.899$ & 0.34 & $9 / 2.804$ & 0.32 \\
\hline Blumenau & $36 / 13.704$ & 1.03 & $81 / 13.407$ & 0.60 & $74 / 12.580$ & 0.59 \\
\hline Jaraguá do Sul & $9 / 2.201$ & 0.26 & $1 / 2.317$ & 0.04 & $5 / 2.888$ & 0.17 \\
\hline Total & 346/91.358 & 0.38 & $262 / 84.376$ & 0.31 & $304 / 88.241$ & 0.34 \\
\hline
\end{tabular}


those found in Germany population during the same period, while the frequency of the marker of $\mathrm{HCV}$ infection (anti-HCV) was approximately 50\% lower [29], though it was approximately five times greater than that found between 1991 and 1993 in blood donors in the United States [30].

The reduction in the prevalence of markers of $\mathrm{HBV}$ and HCV infection, which signified a significant reduction in the residual risk of transmission of these infections through blood transfusion, may be attributed to the introduction of the third generation ELISA tests, which increased the detection sensitivity for these viruses, reducing the window of detection, and also due to the effort employed by the blood banks in recruiting a greater number of volunteers who donate blood periodically. This is also a consequence of the efforts aimed at detecting behavior that increases the risk of infection by these viral agents and by HIV [21,31], which results in the exclusion and/or autoexclusion of suspect donors. This reduction is also due to recent efforts to vaccinate children and fertile age women against hepatitis $B$.

Nevertheless, a residual risk of transmission of HBV and HCV by transfusion of contaminated blood persists, as a consequence of the infectious window period [21]. This risk could be reduced even more through the introduction of tests based on the polymerase chain reaction (PCR) or the increase in nucleic acids (NAT), since these tests, developed at the end of the last decade [32-35] have greater sensitivity and specificity, thereby decreasing the amplitude of the infectious window period and the residual risk of transmission via blood transfusion. However, although the cost-benefit relation may seem low for developed countries, developing counties are evaluating their utilization in areas where high prevalence of these infections has been found [21].

The average residual risks of transmission of HBV and HCV infection, 1:2077 and 1:13721, respectively, is still very high in Florianópolis, SC, Brasil, [21], when we compare these figures to those known from the United States in 1996, 1:63,000 and 1:103,000, respectively [36].
Given the high prevalence of HBV markers in the different regions of the state of Santa Catarina, the high risk of transmission of $\mathrm{HBV}$ infection through transfusions and the high degree of success attained by the mass vaccination programs against hepatitis B, implemented in Taiwan and Saudi Arabia, which resulted in drastic reductions in the prevalence of $\mathrm{HbsAg}$ and anti-HBc markers in the populations of these two countries, after 8 and 15 years, respectively [37,38], efforts should be made to implement mass hepatitis B vaccination campaigns for the population from 0-15 years of age and for fertile age women, in order to reduce the prevalence of $\mathrm{HBV}$ among the population and thereby more rapidly reduce the risk of transmission of this virus. This type of measure seems to be even more urgent in regions of high prevalence, such as Chapecó, located in western Santa Catarina, where the prevalence of $\mathrm{HbsAg}$ and anti-HBc markers among blood donors, found from 1999 to 2001, was approximately three times greater than the state average; sexual transmission and transmission through blood transfusions may be interacting in this region, increasing the total risk of transmission of HBV and thereby progressively increasing the prevalence of the markers of this infection.

\section{References}

1. Schreiber G.B., Busch M.P., Kleinman S.H., Korelitz J.J. The risk of transfusion-transmitted viral infections. The Retrovirus Epidemiology Donor Study. N Engl J Med 1996;334(26):1685-90.

2. Kleinman S., Busch M.P., Korelitz J.J., Schreiber G.B. The incidence/window period model and its use to assess the risk of transfusion-transmitted human immunodeficiency virus and hepatitis $\mathrm{C}$ virus infection. Transfus Med Rev 1997;11(3):155-72.

3. Gonçales Junior F.L. Prevenção das hepatites póstransfusionais. In: Covas, D.T. \& Zago, M.A. eds.Atualização em Hemoterapia, vol. 5, Ribeirão Preto: Gráfica Canavaci 1998.

4. Wright T.L., Hollander H., Pu X., Held M.J. Hepatitis C in HIV-infected patients with and without AIDS: prevalence and relationship to patient survival. Hepatology 1994;20(5):1152-5. 
5. Benvegnu L., Fattovich G., Noventa F., et al. Concurrent hepatitis $\mathrm{B}$ and $\mathrm{C}$ virus infection and risk of hepatocellular carcinoma in cirrhosis. A prospective study. Cancer 1994;74(9):2442-8.

6. Kaklamani E., Trichopoulos D., Tzonou A., et al. Hepatitis $\mathrm{B}$ and $\mathrm{C}$ viruses and their interaction in the origin of hepatocellular carcinoma. JAMA 1991;265(15):1974-6.

7. El-Refaie A., Savage K., Bhattacharya S., et al. HCVassociated hepatocellular carcinoma without cirrhosis. J Hepatol 1996;24(3):277-85.

8. Simonetti R.G., Camma C., Fiorello F., et al. Hepatitis C virus infection as a risk factor for hepatocellular carcinoma in patients with cirrhosis. A case-control study. Ann Intern Med 1992;116(2):97-102.

9. Kao J.H., Chen P.J., Lai M.Y., Chen D.S. Occult hepatitis B virus infection and clinical outcomes of patients with chronic hepatitis C. J Clin Microbiol 2002;40(11):4068-71.

10. Sánches N.M., González H.B., Gómez R.H.S., et al. Prevalência de hepatitis $\mathrm{B}$ y $\mathrm{C}$ em donadores de sangre em um hospital de tercer 'veç de Ciudad de México. Salud Publica de México. 1999;41(6):475-8.

11. Frider B. Epidemiologia de laof hepatitis C. Acta Gastroenterol Latinoam 2000;30(2):142-4.

12. Zou S., Tepper M., Giulivi A. [Current status of hepatitis C in Canada.] Can J Public Health 2000;91 Suppl 1:S10-5, S10-6.

13. Sato S., Fujiyama S., Tanaka M., et al. Coinfection of hepatitis $\mathrm{C}$ virus in patients with chronic hepatitis $\mathrm{B}$ infection. J Hepatol 1994;21(2):159-66.

14. Ohkawa K., Hayashi N., Yuki N., et al. Hepatitis C virus antibody and hepatitis $\mathrm{C}$ virus replication in chronic hepatitis B patients. J Hepatol 1994;21(4):509-14.

15. Fattovich G., Tagger A., Brollo L., et al. Hepatitis C virus infection in chronic hepatitis B virus carriers. J Infect Dis 1991;Feb;163(2):400-2

16. Crespo J., Lozano J.L., de la Cruz F., et al, Prevalence and significance of hepatitis $\mathrm{C}$ viremia in chronic active hepatitis B. Am J Gastroenterol 1994;89(8):1147-51.

17. Chu C.M., Sheen I.S., Liaw Y.F. The role of hepatitis $C$ virus in fulminant viral hepatitis in an area with endemic hepatitis A and B. Gastroenterology 1994;Jul;107(1):189-95.

18. Zarski J.P., Bohn B., Bastie A.,et al. Characteristics of patients with dual infection by hepatitis $B$ and $C$ viruses. J Hepatol. 1998;28(1):27-33.

19. Kupek E.J. Residual transfusion risk for hepatitis B and C in southern Brazil, 1991-99. J Viral Hepat 2001;8(1):78-82.

20. www.anvisa.org.br. consulted June $\mathbf{2 0 0 2}$

21. Zuck T.F. Transfusion-transmitted AIDS reassessed. N Engl J Med 1988;318(8):511-2.

22. Glynn S.A., Kleinman, S.H., Schreiber, G.B., et al. Trends in incidence and prevalence of major transfusiontransmissible viral infections in US blood donors, 1991 to 1996. Retrovirus Epidemiology Donor Study (REDS) JAMA 2000;284(2):229-35.
23. Kleinman S. Blood donor screening: principles and policies. In: Petz, L.D., Swisher, S.N., Kleinman, S., Spence, R.K., Strauss, R.G., edsa. ClinicalPractice of Transfusion Medicine. $3^{\text {rd }}$ ed.New York, NY: Churchill Livinstone INC;1996;245-70.

24. Alter H.J., Conry-Cantilena C., Melpolder J., et al. Hepatitis $\mathrm{C}$ in asymptomatic blood donors. Hepatology. 1997;26(3 Suppl 1):29S-33S.

25. Alter M.J., Kruszon-Moran D., Nainan O.V., et al. The prevalence of hepatitis $\mathrm{C}$ virus infection in the United States, 1988 through 1994. N Engl J Med 1999;341(8):556-62.

26. Jilg W., Hottentrager B., Weinberger K., et al. Prevalence of markers of hepatitis B in the adult German population. J Med Virol 2001;63(2):96-102

27. Martelli C.MT., Turchi M.D., Souto F.J.D. et al. Anti-HBc testing for blood donations in areas with intermediate hepatitis B endemicity. Rev Panam Salud Publica 1999;6(1):69-73.

28. Treitinger A., Spada C., Ferreira L.A., et al. Hepatitis B and hepatitis $\mathrm{C}$ prevalence among blood donors and HIV-1 infected patients in Florianopolis_-Brazil. Braz J Infect Dis 2000;4(4):192-6.

29. Palitzsch K.D., Hottentrager B., Schlottmann K., et al. Prevalence of antibodies against hepatitis $\mathrm{C}$ virus in the adult German population. Eur J Gastroenterol Hepatol. 1999;11(11):1215-20.

30. Korelitz J.J., Busch M.P., Kleinman S.H., et al. Relationship between antibody to hepatitis B core antigen and retroviral infections in blood from volunteer donors. Transfusion 1996;36(3):232-7.

31. Kupek E.J. HIV seroprevalence among blood donors in southern Brazil in the decade of 1990. Braz J Infect Dis 2000;4(5):217-25.

32. Schottstedt V., Tuma W., Bunger G., Lefevre H. PCR for $\mathrm{HBV}, \mathrm{HCV}$ and HIV-1 experiences and first results from a routine screening programme in a large blood transfusion service. Biologicals 1998;26(2):101-4.

33. Yerly S., Pedrocchi M., Perrin L. The use of polymerase chain reaction in plasma pools for the concomitant detection of hepatitis $\mathrm{C}$ virus and HIV type 1 RNA. Transfusion 1998;38(10):908-14.

34. Roth W.K., Weber M., Seifried E. Feasibility and efficacy of routine PCR screening of blood donations for hepatitis $\mathrm{C}$ virus, hepatitis B virus, and HIV-1 in a bloodbank setting. Lancet 1999;353(9150):359-63.

35. Bush M.P., Stramer S.L., Kleinman S.H. Evolving applications of nucleic acid amplifications assays for prevention of virus transmission by blood components and derivates. In: Garratty, G., ed. Applications of Molecular Biology in Blood Transfusion. Bethesda, Md: American Association of Blood Banks 1997:123176. 
36. Goodnough L.T., Brecher M.E., Kanter M.H., AuBuchon J.P. Transfusion medicine. First of two parts-blood transfusion. N Engl J Med 1999;340(6):438-47.

37. Ni Y.H., Chang M.H., Huang L.M., et al. Hepatitis B virus infection in children and adolescents in a hyperendemic area: 15 years after mass hepatitis B vaccination. Ann Intern Med 2001;135(9):796-800.

38. Al-Faleh F.Z., Al-Jeffri M., Ramia S., et al. Seroepidemiology of hepatitis B virus infection in Saudi children 8 years after a mass hepatitis B vaccination programme. J Infect 1999;38(3): 167-70. 